\title{
Bacteria from Wheat and Cucurbit Plant Roots Metabolize PAHs and Aromatic Root Exudates: Implications for Rhizodegradation
}

Ely, Cairn S; Smets, Barth F.

Published in:

International Journal of Phytoremediation

Link to article, DOI:

10.1080/15226514.2017.1303805

Publication date:

2017

Document Version

Peer reviewed version

Link back to DTU Orbit

Citation (APA):

Ely, C. S., \& Smets, B. F. (2017). Bacteria from Wheat and Cucurbit Plant Roots Metabolize PAHs and Aromatic Root Exudates: Implications for Rhizodegradation. International Journal of Phytoremediation, 19(10), 877-883. https://doi.org/10.1080/15226514.2017.1303805

\section{General rights}

Copyright and moral rights for the publications made accessible in the public portal are retained by the authors and/or other copyright owners and it is a condition of accessing publications that users recognise and abide by the legal requirements associated with these rights.

- Users may download and print one copy of any publication from the public portal for the purpose of private study or research.

- You may not further distribute the material or use it for any profit-making activity or commercial gain

- You may freely distribute the URL identifying the publication in the public portal 


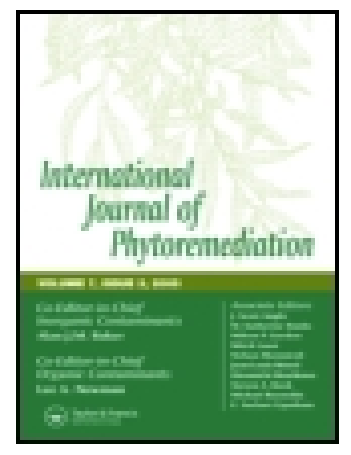

International Journal of Phytoremediation

ISSN: 1522-6514 (Print) 1549-7879 (Online) Journal homepage: http://www.tandfonline.com/loi/bijp20

\section{Bacteria from Wheat and Cucurbit Plant Roots Metabolize PAHs and Aromatic Root Exudates: Implications for Rhizodegradation}

\section{Cairn S. Ely \& Barth F. Smets}

To cite this article: Cairn S. Ely \& Barth F. Smets (2017): Bacteria from Wheat and Cucurbit Plant Roots Metabolize PAHs and Aromatic Root Exudates: Implications for Rhizodegradation, International Journal of Phytoremediation, DOI: 10.1080/15226514.2017.1303805

To link to this article: http://dx.doi.org/10.1080/15226514.2017.1303805

Accepted author version posted online: 20

Mar 2017.

Submit your article to this journal $\widetilde{ }$

山 Article views: 7

Q View related articles ¿

View Crossmark data $\asymp$ 


\title{
ACCEPTED MANUSCRIPT
}

Rhizobacteria Metabolize PAHs and Aromatic Root Exudates

Bacteria from Wheat and Cucurbit Plant Roots Metabolize PAHs and Aromatic Root Exudates:

Implications for Rhizodegradation

Cairn S. Ely ${ }^{1 *}$, Barth F. Smets ${ }^{2}$

${ }^{1}$ Department of Engineering, Central Connecticut State University, New Britain, CT, 06050 USA

${ }^{2}$ Department of Environmental Engineering, Technical University of Denmark, 2800 Lyngby,

Denmark

*Corresponding author: Tel.:860-832-1861, Email: Cairn.Ely@ ccsu.edu

\begin{abstract}
The chemical interaction between plants and bacteria in the root zone can lead to soil decontamination. Bacteria which degrade PAHs have been isolated from the rhizospheres of plant species with varied biological traits, however, it is not known what phytochemicals promote contaminant degradation. One monocot and two dicotyledon plants were grown in PAH-contaminated soil from a manufactured gas plant (MGP) site. A phytotoxicity assay confirmed greater soil decontamination in rhizospheres when compared to bulk soil controls. Bacteria were isolated from plant roots (rhizobacteria) and selected for growth on anthracene and chrysene on PAH-amended plates. Rhizosphere isolates metabolized 3- and 4-ring PAHs and PAH catabolic intermediates in liquid incubations. Aromatic root exudate compounds, namely flavonoids and simple phenols, were also substrates for isolated rhizobacteria. In particular, the
\end{abstract}




\section{ACCEPTED MANUSCRIPT}

phenolic compounds -- morin, caffeic acid, and protocatechuic acid -- appear to be linked to bacterial degradation of 3- and 4- ring PAHs in the rhizosphere.

\section{Keywords}

rhizosphere, polycyclic aromatic hydrocarbons, flavonoids, siderophores 


\section{ACCEPTED MANUSCRIPT}

\section{INTRODUCTION}

Pollution of soil with toxic aromatic hydrocarbons is widespread and often due to historic waste disposal methods at petroleum-based industrial sites. Polycyclic aromatic hydrocarbons (PAHs) are a class of these compounds which impact human health through interactions with DNA that lead to mutations and cancer (Alkio, Tabuchi et al. 2005). The toxicity of PAHs, the quantity of polluted sites, and the expense in remediating coal tar residues has necessitated the development of cost-effective treatment options.

Rhizodegradation is emerging as a potential remediation technology for organic pollutants in soil. This form of phytoremediation utilizes the natural interaction of plants and rhizosphere bacteria to decontaminate the surrounding soil. For example, elevated degradation of phenanthrene was seen for rhizosphere soils planted with slender oat (Avena barbata) when compared to bulk soil controls (Harvey, Campanella et al. 2002). However, it has yet to be determined if rhizodegradation can be a widespread technology option used regularly by treatment industries. In order to improve the extent of removal, it may be necessary to stimulate bacterial degradation through chemical interaction with host plants. The purpose of this study was to evaluate certain compounds that are exuded from plant roots as potential chemical stimulants in rhizodegradation systems.

The resilience of the rhizosphere to chemical disturbance has been attributed to the biochemical interaction of plants and soil microorganisms (Lynch 2002). Plants exude specific compounds to influence microbial population composition and activity in the rhizosphere. For instance, root exudates ward off pathogens (Lynch 1990) and establish soil chemical balance 


\section{ACCEPTED MANUSCRIPT}

through feedback loops with beneficial rhizobacteria (Whipps 1990). Evidence suggests that plants exude aromatic compounds that resemble catabolic intermediates to stimulate biodegradation of toxic aromatic contaminants (Donnelly, Hegde et al. 1994; Walton, Hoylman et al. 1994; Fletcher and Hegde 1995; Siciliano 1998). Examples of these exudate compounds are flavonoids and simple phenols. Bacterial degradation of the contaminant then leads to lower phytotoxic conditions and restores chemical balance in the root zone.

Iron nutrition in the rhizosphere may impact PAH degradation because aerobic bacterial growth on hydrocarbons requires higher iron concentrations (Daane, Harjono et al. 2001). In addition, efficient sequestration of iron can be an important factor in plant-bacteria interaction and root colonization (de Weger, van Arendonk et al. 1988). Dicotyledon plants exude phenolic compounds, which are similar to flavonoids and simple phenols, to scavenge iron from the soil environment. Microorganisms and monocotyledon plants synthesize siderophores to acquire insoluble iron from the soil. Bacterial species that scavenge iron through siderophore production are prevalent in plant root environments (Meyer, Geoffroy et al. 2002; Bultreys, Gheysen et al. 2003). In this study, siderophore production by PAH-degrading root isolates is assessed to see if this may be another factor in rhizodegradation.

The reaction of plants to PAH contamination and the influence on rhizosphere microbes can impact the choice of a host plant for a rhizodegradation system. A variety of plants remediate petroleum hydrocarbon pollution in soil including hybrid poplar, cattail, and rice (Adams, Carroll et al. 2000; Farrell, Frick et al. 2000). Grasses and legumes have been the predominant type of plants used in rhizodegradation studies (Frick, Farrell et al. 1999; Farrell, Frick et al. 


\section{ACCEPTED MANUSCRIPT}

2000). Factors such as the size of the root system and plant-soil chemical interaction can impact the extent of contaminant removal (Adams, Carroll et al. 2000).

The three plant varieties in this study are agricultural crops which have benefits such as short growth periods and potential for use in large-scale phytoremediation applications. However, test plants used for treatment could not be food sources due to the potential for accumulation of toxic amounts of the pollutant. Wheat plants, which are members of the grass family (Poacea), have been shown to promote removal of naphthalene, a 2- ring PAH (Kuiper, Kravchenko.L.V. et al. 2002). The fibrous root systems of grasses may penetrate to a depth of $3 \mathrm{~m}$ (Frick, Farrell et al. 1999). In addition, microscopic root hairs which protrude from the main roots of these plants create a vast surface area for interaction with micro-inhabitants.

PAHs are highly hydrophobic and adsorb strongly to the soil matrix. Mobilizing these compounds increases bioavailability which, in turn, enhances bacterial degradation (Liste and Alexander 2000). Zucchini and pumpkin plants (Cucurbitae) exude organic acids which withdraw hydrophobic organic pollutants in the soil (White and Kottler 2002; White, Mattina et al. 2003). Zucchini plants accumulate PAHs at surprising concentrations (Parrish, White et al. 2006) given the unlikelihood of PAH translocation into the root interior.

Rhizobacteria were isolated from the plant species grown in PAH-contaminated soil and selected for growth on anthracene and chrysene. PAH-utilizing isolates were then assayed for growth on aromatic exudates and production of siderophores to test chemical interactions which may promote degradation of PAHs by rhizobacteria.

\section{MATERIALS AND METHODS}




\section{ACCEPTED MANUSCRIPT}

\section{Plant growth conditions}

Wheat seeds were obtained from a laboratory at the University of Connecticut (Storrs, CT). Zucchini and pumpkin seeds were obtained from Seedway (Elizabethtown, PA). Latin names and cultivars for these plants are listed in Table 1 . Seeds were disinfected by shaking in a $3 \% \mathrm{HClO}_{3}$ solution for 2 hours. Germination of seeds took place in sterile water agar plates $(1 \mathrm{~L}$ water with $15 \mathrm{~g}$ agar, autoclaved). After radicles emerged, the seedlings were planted in the soil mixture. The soil mixture contained PAH-contaminated soil from a former manufactured gas plant site in Winsted, CT (MGP soil). The total PAH concentration in the MGP soil was 760 ppm. The soil mixture contained $0 \%$ (control), $3 \%$, or $30 \%(\mathrm{v} / \mathrm{v})$ of the contaminated soil (referred to as 0-MGP, 3-MGP, and 30-MGP). Early trials showed that seedling survival rates at higher concentrations would not provide enough samples for adequate analysis. The rest of the soil mixture was comprised of a pristine soil and a small amount of sterile peat moss to elevate water retention. The pristine soil was obtained from the Connecticut Agricultural Experiment Station research farm in Cheshire, CT. Plants grew at room temperature $\left(24^{\circ} \mathrm{C}\right)$ for two months. A 16-hour photoperiod was supplied through four 40W Plant and Aquarium fluorescent bulbs (General Electric Company, Cleveland, $\mathrm{OH}$ ). Plants were bottom-watered and misted daily with sterile water. Weekly fertilizations were supplied with $10 \mathrm{~mL}$ of sterile $10 \%$ Hoagland's solution. The plants were harvested after two months growth in the potting media. Shoots were severed at the root-shoot interface using a sterile scalpel.

\section{Obtaining rhizosphere bacteria}




\section{ACCEPTED MANUSCRIPT}

Roots were carefully removed from potting media under sterile conditions. Except for large dry clumps, the majority of the soil adhering to the roots was included as part of the rhizosphere -based on the common definition of the rhizosphere as a zone of physical and chemical interaction between the root and the surrounding soil. Roots were placed in $40 \mathrm{~mL}$ of $0.1 \mathrm{M}$ potassium phosphate buffer (PPB) and sonicated using a sonic dismembrator wand for 30 seconds at setting 4, which translates to 8-11 Watts depending on solution density. Sonicant was allowed to settle for 10 min so soil would separate out and the liquid phase was collected. Suspensions were spun down at $10000 \mathrm{x}$ g for $20 \mathrm{~min}$, the supernatant removed, and the pellet re-suspended in $1 \mathrm{~mL}$ of $0.1 \mathrm{M}$ PPB.

\section{Selecting PAH-degrading bacteria}

Rhizosphere suspensions were vortexed to mix and $50 \mu \mathrm{L}$ aliquots withdrawn and spread on mineral salts minimal media (MSMM) plates prepared with noble agar. The plates were sprayed with one of two PAH/solvent substrate solutions: $500 \mathrm{mg} / \mathrm{L}$ anthracene in hexanes and $500 \mathrm{mg} / \mathrm{L}$ chrysene in hexanes. Sprays of the substrate solutions were applied to the plates using glass aspirator bottles (20-30 sprays). The hexanes immediately evaporated off leaving a uniform coating of either anthracene or chrysene on the selection plates. These plates were allowed to incubate for 30 days at room temperature $\left(24^{\circ} \mathrm{C}\right)$. Bacteria were selected based on the formation of clearing zones of the PAHs around the colonies (See Figure 2). Colonies were located using a microscope at 10x magnification and spread on $0.1 \mathrm{R}_{2} \mathrm{~A}$ plates amended with $100 \mathrm{mg} / \mathrm{L}$ cyclohexamide and incubated at $30^{\circ} \mathrm{C}$ for 2 days. Single colonies were then purified by T- 


\section{ACCEPTED MANUSCRIPT}

streaking on a second $0.1 \mathrm{R}_{2} \mathrm{~A}$ plate. Purified isolates were grown in liquid $0.1 \mathrm{R}_{2} \mathrm{~A}$ media for 2 days at $30^{\circ} \mathrm{C}$ and stored in $60 \%(\mathrm{v} / \mathrm{v})$ glycerol at $-80^{\circ} \mathrm{C}$.

\section{Soil phytotoxicity test after plant harvest}

A phytotoxicity assay was used to determine if conditions in the contaminated soil were improved by the plants after the growth period. This method estimates the acute toxicity of solid hazardous wastes in a 120-hour static test. Lactuca sativa var. Tango was used as the test species. The number of seeds that germinate in the soil is the measurement of phytotoxicity. The assay was performed for rhizospheres at the 30-MGP level and a non-planted control (bulk soil). After root harvest, $25 \mathrm{~g}$ of the soil mixture was placed in a Petri dish and 40 lettuce seeds were evenly distributed on the soil surface. Another $20 \mathrm{~g}$ of the same soil was then lightly spread over the seeds. $10 \mathrm{~mL}$ of sterilized reverse osmosis (RO) water was applied with a pipette to provide adequate moisture during germination. The Petri dish was closed and sealed with parafilm. The Petri dishes were incubated in the dark at room temperature for 2 days and then moved into the light at room temperature for 3 days. The lighting supplied was from natural sunlight through windows and fluorescent lights used to light the room. After 5 days of incubation the number of lettuce sprouts protruding above the soil surface was counted.

\section{Growth of PAH-utilizing bacteria on substrates in liquid incubations}

Bacteria isolated and purified from PAH selection plates were assayed for growth on additional PAHs, PAH catabolic intermediates, aromatic root exudates, and two major plant hormones. These compounds are supplied as the only carbon and energy source during the initial incubation period. Microplates were amended with anthracene, chrysene, fluoranthene, 


\section{ACCEPTED MANUSCRIPT}

phenanthrene, and pyrene. An aliquot of $40 \mathrm{uL}$ PAH stock solution (500 mg/L in hexanes) was added to the test wells and the hexanes allowed to evaporate off leaving a layer of PAH on the microwell bottom. Next, $150 \mu \mathrm{L}$ of mineral salts minimal media (MSMM) was then added to the wells $(\mathrm{pH}=7)$.

Compounds which were adequately soluble in water, such as salicylate, were prepared directly in MSMM (133.33 mg/L) and $150 \mu \mathrm{L}$ of this solution was added to the microwells. Control wells contained either $150 \mu \mathrm{L}$ of MSMM with the inoculum but no substrate or $200 \mu \mathrm{L}$ of MSMM with a substrate but no inoculum. Aliquots of $50 \mu \mathrm{L}$ cell suspensions were then added to the appropriate wells in the substrate-amended microplates. Addition of the inoculum resulted in a final concentration of each test compound of $100 \mathrm{mg} / \mathrm{L}$ for all compounds tested. Microplates were then covered and placed in clean plastic bags with $3 \mathrm{~mL}$ sterile RO water to maintain moisture content throughout the incubation period. After 3 weeks, $10 \mu \mathrm{L}$ of WST-1 tetrazolium salt dye (Roche, Cat. \# 1644807) was added to all wells in each microplate with a multichannel pipetter. Tetrazolium salts like WST-1 are reduced to a colored formazan only by metabolically active cells, meaning this assay detects viable cells exclusively. An additional carbon source was then added to the microplates $(50 \mu \mathrm{L})$. This additional carbon source consisted of a filter-sterilized solution of $16.6 \mathrm{mM}$ glucose, $16.6 \mathrm{mM}$ succinate, and $16.6 \mathrm{mM}$ pyruvate in $40 \mathrm{mM}$ Tris buffer at a $\mathrm{pH}$ of 6.5. Absorbance readings were then taken after twelve hours with a microplate reader. Absorbance was measured at $450 \mathrm{~nm}$ for the formazan product and $630 \mathrm{~nm}$ for cell optical density. $\mathrm{Abs}_{630}$ was then subtracted from $\mathrm{Abs}_{450}(\Delta \mathrm{Abs})$. Adjusted readings were then calculated as $\Delta$ Abs.(Test wells) -- $\Delta$ Abs.(Controls). Positive metabolism of test compounds due to formazan formation was then assigned to the normalized values greater 


\section{ACCEPTED MANUSCRIPT}

than 0.5 , leading to a reading in the test wells that is 1.5 times greater than that of the corresponding controls. Control wells without any inoculum but added substrate were included as a sterility control.

\section{Siderophore production assay}

The production of siderophores was assayed by adding bacterial cells to Chromo Azurol S (CAS) plates. CAS plates were prepared by de-ferrating casamino acids. First, $10 \mathrm{~g}$ casamino acids were dissolved in $100 \mathrm{~mL}$ sterile deionized water. Casamino acids solution was extracted with an equal volume of 3\% 8-hydoxyquinoline in chloroform to remove iron. An equal volume of chloroform was then added to withdraw 8-hydroxyquinoline. CAS-HDTMA solution was prepared by adding $605 \mathrm{mg}$ Chromo azurol S to $500 \mathrm{~mL}$ deionized water, adding $100 \mathrm{~mL} 1 \mathrm{mM}$ $\mathrm{FeCl}_{3}$ in $10 \mathrm{mM} \mathrm{HCl}$, and slowly pouring this mixture into hexadecyltrimethylammonium bromide (HDTMA) solution -- 729 mL HDTMA with 400 mL water. CAS agar, containing 750 $\mathrm{mL}$ sterile deionized water, $6 \mathrm{~g} \mathrm{NaOH}, 30.24 \mathrm{~g}$ of PIPES, $100 \mathrm{~mL} 10$ x MM9, and $15 \mathrm{~g}$ agar, was then prepared and autoclaved. Next, $30 \mathrm{~mL}$ deferrated casamino acids, $10 \mathrm{~mL}$ of $20 \%$ glucose, 1 $\mathrm{ml}$ of $1 \mathrm{M} \mathrm{MgCl}_{2}$, and $1 \mathrm{~mL}$ of $100 \mathrm{mM} \mathrm{CaCl}_{2}$ were then added to the sterile $900 \mathrm{~mL}$ CAS agar. To this solution, $100 \mathrm{~mL}$ of CAS-HDTMA solution was gently added and plates were poured. Cells were grown in 0.25 TSB and contacted with the CAS plates with an inoculation loop. Siderophore production of PAH-utilizing bacterial isolates was measured by observing the development of orange-yellow halos around colonies.

\section{RESULTS}




\section{ACCEPTED MANUSCRIPT}

The germination test results in Figure 1 confirmed that all plants decrease the toxicity of the MGP contamination over non-planted controls (bulk MGP). Single factor Analysis of Variance (ANOVA) was performed on the data and resulted in an F critical of 4.757. Comparison with variance values indicated that Wheat and Cucurbits samples were not statistically different $($ Variance $=5.333$ and 14.333, respectively $)$, but the Bulk MGP soil was $($ Variance $=1.963)$ indicating that the untreated Bulk MGP soil was more phytotoxic that the soil contacted with test plants. More seeds germinated for the cucurbits, indicating that these plants are better at reducing PAH contamination than wheat.

Rhizosphere bacteria were obtained from harvested plant roots and colonies selected based on clearing zones of the PAHs (Fig. 2). PAH-metabolizing bacteria were isolated from the rhizospheres of all plant varieties at each MGP level. Isolates from the 3-MGP level were subjected to growth assays on 3- and 4- ring PAHs and PAH catabolic intermediates. The results from this tetrazolium salt assay (Table 2a) indicated that isolates grew on anthracene, chrysene, flouranthene, phenanthrene, and pyrene as sole carbon and energy source in liquid suspensions. Fluoranthene was metabolized the most of the PAHs tested, especially for isolates from wheat plants. These root-zone bacteria also grew on catabolic intermediate compounds, gentisate, protocatechate and salicylate. Practically all $\mathrm{PAH}$-metabolizing isolates from test plants grew on protocatechuic acid, a common intermediate in the degradation pathway of 3- and 4-ring PAHs. Isolates of the cucurbits grew more readily on gentisate than those of wheat. Only a few wheat isolates grew on salicylate, an intermediate compound of naphthalene degradation. 


\section{ACCEPTED MANUSCRIPT}

PAH-metabolizing bacteria from the rhizosphere grew on aromatic exudates and plant hormones as a sole carbon and energy source (Table 2b). Isolates from the cucrubits grew more readily on the simple phenols, flavonoids, and gibberellic acid. Isolates from wheat grew more readily on IAA. In total, caffeic acid and morin were utilized the most, $98.6 \%$ and $96.0 \%$ respectively, for the root exudate compounds.

Results from the Chromo Azurol S (CAS) plate assay show that all isolates from the uncontaminated 0\% MGP rhizospheres produced siderophores (Table 3). Siderophore production reduced sharply as the level of MGP soil contamination increased. Isolates from the 30-MGP rhizospheres had the lowest percentage of siderophore production at $29.4 \%$. Isolates from wheat plants show higher percentages of siderophore production than the isolates of the cucurbits.

\section{DISCUSSION}

To serve as a host plant in a rhizodegradation system, a plant species must be capable of growing in contaminated soil and supporting a bacterial population with activity towards the contaminant. This study addressed the following question concerning the plant-bacteria interaction: What phytochemicals are likely to play a role in promoting PAH rhizodegradation? Assessing the metabolism of root exudates by rhizosphere bacteria may then indicate what plants-bacteria combinations and chemical conditions promote the highest level of PAH degradation.

Bacterial isolates from the rhizospheres of plants grown in 3-MGP tested positive for growth on 3- and 4- ring PAHs. The percentage of metabolism by isolates ranged from $30.6 \%$ to $69.4 \%$. It appears that some of these rhizobacteria, which were selected on solid agar plates, cannot utilize 3- and 4- ring PAHs in aqueous substrate incubations. The highest percentage of metabolism 


\section{ACCEPTED MANUSCRIPT}

occurred with fluoranthene suggesting that wheat rhizobacteria are more familiar with this compound. The ability of these bacteria to grow on these different hydrocarbons is not surprising. Single strains of bacteria (Mycobacterium sp.) have been shown to degrade a range of PAHs including phenanthrene and anthracene (Moody, Freeman et al. 2001), fluoranthene (Rehmann, Hertkorn et al. 2001), and pyrene (Kazunga and Aitken 2000). This catabolic ability is likely due to convergence in the respective catabolic pathways. For instance, pyrene degradation leads to the phenanthrene catabolic pathway (Ellis, Roe et al. 2006).

Protocatechuic acid was metabolized almost universally by the rhizobacteria. Protocatechuate is a common intermediate compound in the degradation pathway for several 3- and 4- ring PAHs, such as phenanthrene (Ellis, Roe et al. 2006). Salicylic acid was barely utilized which is not expected as salicylic acid induces enzymes in the mineralization of naphthalene (Bosch, Moore et al. 1999). It is possible that these bacteria that were selected for growth on 3- and 4- ring PAHs do not metabolize naphthalene, a compound that has only two benzene rings.

Rhizobacteria isolates show high rates for flavonoids and related phenolic exudates, suggesting that growth on PAHs and aromatic exudates is related. In a study of PCB-degrading bacteria, exposure to flavonoids encouraged the utilization of PCBs (Singer, Crowley et al. 2003). Bacterial strains also grow on a wide variety of compounds including naringenin, catechin, coumarin, morin, quercetin, chrysin, and myricetin (Leigh, Fletcher et al. 2002). In this study, the compounds caffeic acid and morin were metabloized at high rates by the isolates, suggesting that these compounds promote $\mathrm{PAH}$ degradation by rhizobacteria. The chemical structure of caffeic acid is the most similar to protocatechuic acid (Figures $3 \mathrm{a}$ and $3 \mathrm{~b}$ ) for the 


\section{ACCEPTED MANUSCRIPT}

simple phenols tested. Additionally, fluoranthene, which was the most utilized PAH, would be similar in structure to the flavonoids upon hydroxylation and initial ring cleavage. A possible reason for the link between degradation of aromatic pollutants and exudate utilization is enzymesubstrate specificity. For example, a modified biphenyl dioxygenase from Pseudomonas pseudoalcaligenes KF707 and Burkholderia cepacia LB400 transformed flavone and flavanone substrates (Chun, Ohnishi et al. 2003).

The exact composition of root exudates for the plant species tested is not known. However, compounds similar to those used in this study have been found in the plant material of wheat and pumpkin plants and listed in a phytochemical database (zucchini not included in phytochemical database) (Duke). In general, the rhizobacteria from the cucurbits grew on the simple phenols and flavonoids more than isolates from wheat host plants. Considerably higher metabolism rates of GA3 was also shown for bacterial isolates from the cucurbits. Gibberellic acid (GA3) is a major plant hormone which, at low concentrations, promotes cell growth and elongation (Hartmann 2002). Conversely, greater utilization of IAA was shown for wheat isolates. Indole-3acetic acid (IAA) is another major plant hormone, classified as an auxin, which promotes root initiation and development (Hartmann 2002). It is surprising that such low utilization was seen for this auxin as bacteria which degrade IAA are known to be widely associated with plants (Leveau and Lindow 2005).

Iron signaling mechanisms may play a significant role in plant-bacteria interactions in response to organic contaminants. For instance, Burkholderia species from the tomato rhizosphere produced hydroxamate-type siderophores, grew on phenol and benzene and 


\section{ACCEPTED MANUSCRIPT}

possessed aromatic oxgenase genes (Caballero-Mellado, Onofre-Lemus et al. 2007). The chromo azurol S (CAS) assay for siderophore production showed that all 0-MGP rhizobacteria isolates possessed this iron scavenging capability. The amount of siderophore producing isolates decreased significantly, however, as the PAH contamination increased. The decrease in siderophore production may suggest a change in the species of PAH-utilizing bacteria that were isolated at higher contamination levels and/or a change in the primary mode of iron acquisition. Indeed, iron availability can affect rhizosphere microbial community dynamics for plants grown under different iron conditions (Whipps 2001).

In this study, PAH-utilizing bacteria grew on 3- and 4-ring PAHs, catabolic intermediates, aromatic exudates, and plant hormones as carbon substrates. Results also suggest a relation between the level of PAH contamination and the ability or mode of iron acquisition used by rhizobacteria. Growth on root exudates and siderophore production by PAHmetabolizing bacteria appears to be marginally influenced by the host plant species. Additionally, the ability of rhizobacteria to grow PAHs and catabolic intermediates appears to be related to similarity in chemical structure to aromatic root exudates. In particular, high metabolism percentages for caffeic acid and morin suggest these compounds promote $\mathrm{PAH}$ degradation by bacteria in the plant root zone. 


\section{ACCEPTED MANUSCRIPT}

\section{REFERENCES}

Adams, N., D. Carroll, et al. (2000). Introduction to Phytoremediation. Washington, D.C., Environmental Protection Agency.

Alkio, M., T. M. Tabuchi, et al. (2005). "Stress responses to polycyclic aromatic hydrocarbons in Arabidopsis include growth inhibition and hypersensitive response-like symptoms." J. Exp. Bot. 56(421): 2983-2994.

Belles, J. M., R. Garro, et al. (1999). "Gentisic Acid As a Pathogen-Inducible Signal, Additional to Salicylic Acid for Activation of Plant Defenses in Tomato." Molecular Plant-Microbe Interactions 12(3): 227-235.

Bosch, R., E. R. B. Moore, et al. (1999). "NahW, a Novel, Inducible Salicylate Hydroxylase Involved in Mineralization of Naphthalene by Pseudomonas stutzeri AN10." J. Bacteriol. 181(8): 2315-2322.

Bultreys, A., I. Gheysen, et al. (2003). "High-Performance Liquid Chromatography Analyses of Pyoverdin Siderophores Differentiate among Phytopathogenic Fluorescent Pseudomonas Species." Appl. Environ. Microbiol. 69(2): 1143-1153.

Caballero-Mellado, J., J. Onofre-Lemus, et al. (2007). "The Tomato Rhizosphere, an Environment Rich in Nitrogen-Fixing Burkholderia Species with Capabilities of Interest for Agriculture and Bioremediation." Appl. Environ. Microbiol. 73(16): 5308-5319. 


\section{ACCEPTED MANUSCRIPT}

Chun, H.-K., Y. Ohnishi, et al. (2003). "Biotransformation of flavone and flavanone by Streptomyces lividans cells carrying shuffled biphenyl dioxygenase genes." Journal of Molecular Catalysis B: Enzymatic 21(3): 113-121.

Daane, L. L., I. Harjono, et al. (2001). "Isolation and Characterization of Polycyclic Aromatic Hydrocarbon-Degrading Bacteria Associated with the Rhizosphere of Salt Marsh Plants." Appl. Environ. Microbiol. 67(6): 2683-2691.

de Weger, L. A., J. J. van Arendonk, et al. (1988). "Siderophore-mediated uptake of Fe3+ by the plant growth-stimulating Pseudomonas putida strain WCS358 and by other rhizosphere microorganisms." J. Bacteriol. 170(10): 4693-4698.

Donnelly, P. K., R. S. Hegde, et al. (1994). "Growth of PCB-Degrading Bacteria on Compounds from Photosynthetic Plants." Chemosphere 28(5): 981-988.

Duke, J. Dr. Duke's phytochemical and ethnobotanical databases, http://www.ars-grin.gov/duke.

Ellis, L., D. Roe, et al. (2006). "The University of Minnesota Biocatalysis/Biodegradation Database: The First Decade " Nucleic Acids Research 34: 517-521.

Farrell, R. E., C. M. Frick, et al. (2000). "PhytoPet: A Database of Plants that Play a Role in the Phytoremediation of Petroleum Hydrocarbons." Proceedings of the Second Phytoremediation Technical Seminar: 29-40.

Fletcher, J. S. and R. S. Hegde (1995). "Release of Phenols by Perennial Plant-Roots and Their Potential Importance in Bioremediation." Chemosphere 31(4): 3009-3016. 


\section{ACCEPTED MANUSCRIPT}

Frick, C. M., R. E. Farrell, et al. (1999). Assessment of Phytoremediation as an In-Situ Technique for Cleaning Oil-Contaminated Sites. Calgary, AB, Petroleum Technnology Alliance of Canada: 1-82.

Hartmann, H. T., D.E. Kester, F.T. Davies, and R.L. Geneve (2002). Plant Propagation: Principles and Practices. Upper Saddle River, Pearson Education, Inc.

Harvey, P. J., B. F. Campanella, et al. (2002). "Phytoremediation of Polyaromatic Hydrocarbons, Anilines, and Phenols." Environ. Sci. and Pollut. Res. 9(1): 29-47.

Kazunga, C. and M. D. Aitken (2000). "Products from the incomplete metabolism of pyrene by polycyclic aromatic hydrocarbon-degrading bacteria." Applied and Environmental Microbiology 66(5): 1917-1922.

Kuiper, I., Kravchenko.L.V., et al. (2002). "Pseudomonas putida strain PCL1444, Selected for Efiicient Root Colonization and Naphthalene Degradation, Effectively Utilizes Root Exudate Components." Molecular Plant-Microbe Interactions 15(7): 734-741.

Leigh, M. B., J. S. Fletcher, et al. (2002). "Root Turnover: An Important Source of Microbial Substrates in Rhizosphere Remediation of Recalcitrant Contaminants." Environmental Science \& Technology 36(7): 1579-1583.

Leveau, J. H. J. and S. E. Lindow (2005). "Utilization of the Plant Hormone Indole-3-Acetic Acid for Growth by Pseudomonas putida Strain 1290." Appl. Environ. Microbiol. 71(5): 2365-2371. 


\section{ACCEPTED MANUSCRIPT}

Liste, H. and M. Alexander (2000). "Accumulation of Phenanthrene and Pyrene in Rhizosphere Soil." Chemosphere 40: 11-14.

Lynch, J. M. (1990). Microbial Metabolites. The Rhizosphere. J. M. Lynch. Chichester, John Wiley and Sons.

Lynch, J. M. (2002). "Resilience of the Rhizosphere to Anthropogenic Disturbance." Biodegradation 13: 21-27.

Meyer, J.-M., V. A. Geoffroy, et al. (2002). "Siderophore Typing, a Powerful Tool for the Identification of Fluorescent and Nonfluorescent Pseudomonads." Appl. Environ. Microbiol. 68(6): 2745-2753.

Moody, J. D., J. P. Freeman, et al. (2001). "Degradation of Phenanthrene and Anthracene by Cell Suspensions of Mycobacterium sp. Strain PYR-1." Appl. Environ. Microbiol. 67(4): 1476-1483.

Parrish, Z. D., J. C. White, et al. (2006). "Accumulation of weathered polycyclic aromatic hydrocarbons (PAHs) by plant and earthworm species." Chemosphere 64(4): 609-618.

Rehmann, K., N. Hertkorn, et al. (2001). "Fluoranthene metabolism in Mycobacterium sp. strain KR20: identity of pathway intermediates during degradation and growth." Microbiology 147(10): 2783-2794.

Siciliano, S. D., and J. J. Germida (1998). "Mechanisms of phytoremediation: biochemical and ecological interactions between plants and bacteria." Environmental Reviews 6: 65-79. 


\section{ACCEPTED MANUSCRIPT}

Singer, A. C., D. E. Crowley, et al. (2003). "Secondary plant metabolites in phytoremediation and biotransformation." Trends in Biotechnology 21(3): 123-130.

Walton, B. T., A. M. Hoylman, et al. (1994). Rhizosphere Microbial Communities as a Plant Defense Against Toxic Substances in Soils. Bioremediation through Rhizosphere Technology. T. A. Anderson and J. R. Coats. Washington D.C., American Chemical Society.

Whipps, J. M. (1990). Carbon Economy. The Rhizosphere. J. M. Lynch. Chichester, John Wiley and Sons.

Whipps, J. M. (2001). "Microbial interactions and biocontrol in the rhizosphere." J. Exp. Bot. 52(suppl_1): 487-511.

White, J. C. and B. D. Kottler (2002). "Citrate-mediated Increase in the Uptake of Weathered 2,2-bis(p-Chlorophenyl)1,1-dichloroethylene Residues by Plants." Environmental Toxicology and Chemistry 21(3): 550-556.

White, J. C., M. I. Mattina, et al. (2003). "Role of organic acids in enhancing the desorption and uptake of weathered p,p'-DDE by Cucurbita pepo." Environmental Pollution 124(1): 7180.

Yang, C. H., D. E. Crowley, et al. (2001). "16S rDNA fingerprinting of rhizosphere bacterial communities associated with healthy and Phytophthora infected avocado roots." Fems Microbiology Ecology 35(2): 129-136. 


\section{ACCEPTED MANUSCRIPT}

Table 1. Names and classification of plant species in this study.

\begin{tabular}{|l|l|l|l|l|}
\hline Common name & Latin & & Plant & Monocotyledon / Dicotyledon \\
\hline & name & Variety & Family & \\
\hline Wheat & Triticum aestivum & Cavalier & Grass (Poacea) & Monocotyledon \\
\hline Zucchini & Cucurbita pepo & Black Beauty & Pumpkin (Cucurbitae) & Dicotyledon \\
\hline Pumpkin & Cucurbita pepo & Howden & Pumpkin (Cucurbitae) & Dicotyledon \\
\hline
\end{tabular}




\section{ACCEPTED MANUSCRIPT}

Table $2 \mathrm{a}$ and $2 \mathrm{~b}$. Growth of bacteria selected from anthracene and chrysene plates on a) 3-and 4ring PAHs and PAH catabolic intermediates and b) flavonoids, simple phenols, and plant hormones. Percentages of bacterial isolates which tested positive for compound utilization in the assay are listed (Wheat, $n=49$; Cucurbits, $n=25$ ).

$2 a$.

\begin{tabular}{|l|c|c|c|}
\hline Compound & Wheat & Cucurbits & Weighted Avg. \\
\hline Anthracene & 40.8 & 44.0 & 41.9 \\
\hline Chrysene & 30.6 & 48.0 & 60.5 \\
\hline Fluoranthene & 69.4 & 44.1 & 47.3 \\
\hline Phenanthrene & 46.9 & 48.0 & 47.3 \\
\hline Pyrene & 46.9 & 48.0 & 98.7 \\
\hline Protocatechuate & 98.0 & 100.0 & 33.8 \\
\hline Gentisate & 26.5 & 48.0 & 2.7 \\
\hline Salicylate & 4.1 & 0.0 & 98.6 \\
\hline 2b. & & & 77.0 \\
\hline Compound & Wheat & Cucurbits & 79.7 \\
\hline Caffeic Acid & 98.0 & 100.0 & 62.2 \\
\hline Cinnamic Acid & 71.4 & 88.0 & 90.5 \\
\hline Coumaric Acid & 79.6 & 80.0 & Weighted Avg. \\
\hline Naringenin & 53.1 & 80.0 & 92.0 \\
\hline Quercetin & 89.8 & & \\
\hline
\end{tabular}




\section{ACCEPTED MANUSCRIPT}

\begin{tabular}{|l|c|c|c|}
\hline Morin & 93.9 & 100.0 & 96.0 \\
\hline Gibberellic Acid & 32.7 & 56.0 & 40.5 \\
\hline Indole-acetic Acid & 22.5 & 8.0 & 17.6 \\
\hline
\end{tabular}




\section{ACCEPTED MANUSCRIPT}

Table 3. Production of siderophores by PAH-utilizing bacteria from plant rhizospheres. Values are percentages of bacterial colonies that showed pigment change in CAS plates due to iron chelation (Wheat, $n=40$, Cucurbits, $n=40$ ).

\begin{tabular}{|l|l|l|l|}
\hline Rhizosphere & Wheat & Cucurbits & Average \\
\hline 0-MGP & 100 & 100 & 100 \\
\hline 3-MGP & 80.3 & 72.5 & 76.4 \\
\hline $30-$ MGP & 35.7 & 23.0 & 29.4 \\
\hline
\end{tabular}




\section{ACCEPTED MANUSCRIPT}

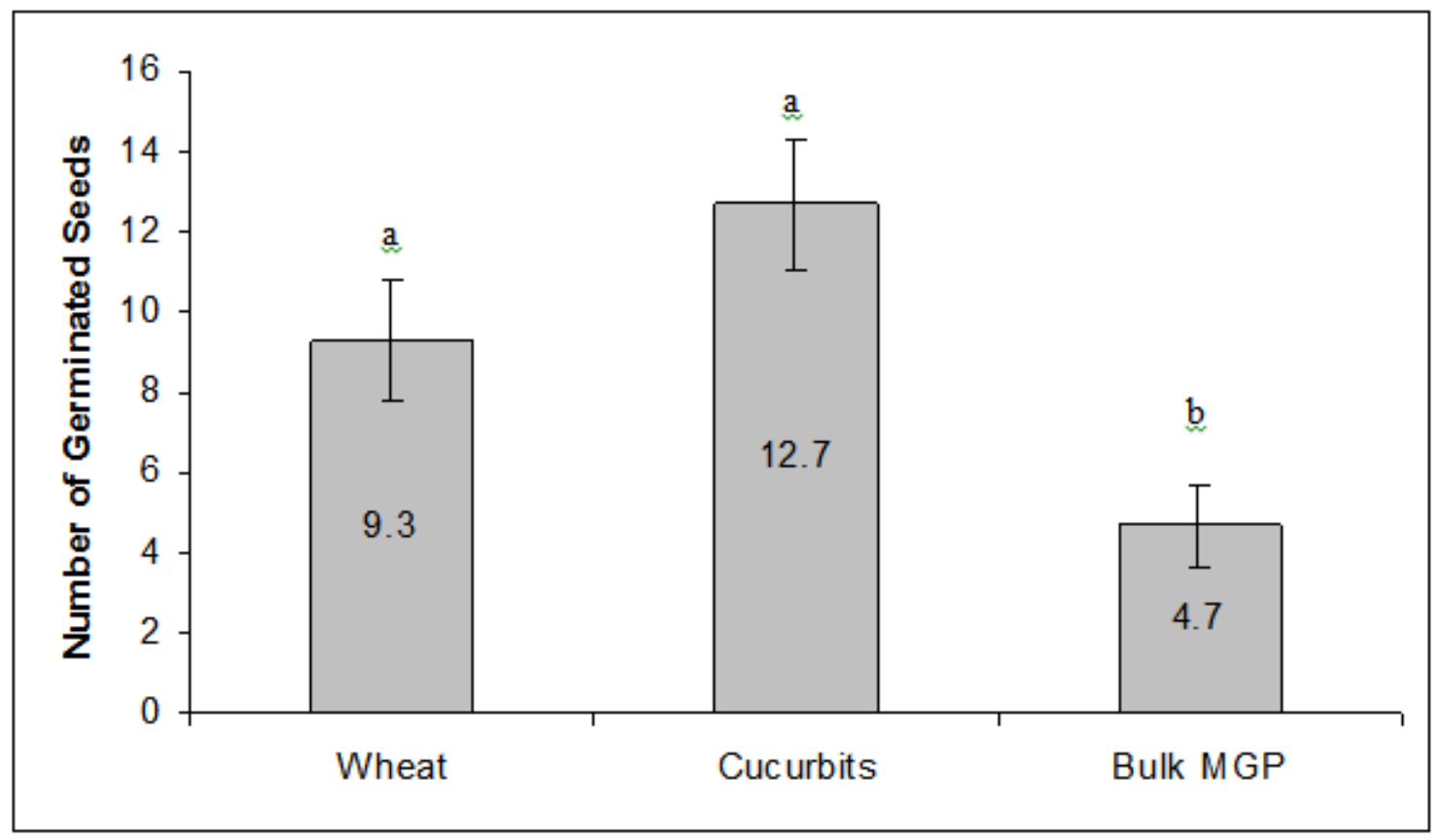

Figure 1. Phytotoxicity assay to measure soil decontamination. "30-MGP" samples were tested including non-plant controls (Bulk MGP) that weathered through the two month growth period. Single factor Analysis of Variance (ANOVA) was performed on the data and indicated that Wheat and Cucurbits samples were not statistically different (a), but the Bulk MGP soil was significantly different than both plant types (b). 


\section{ACCEPTED MANUSCRIPT}

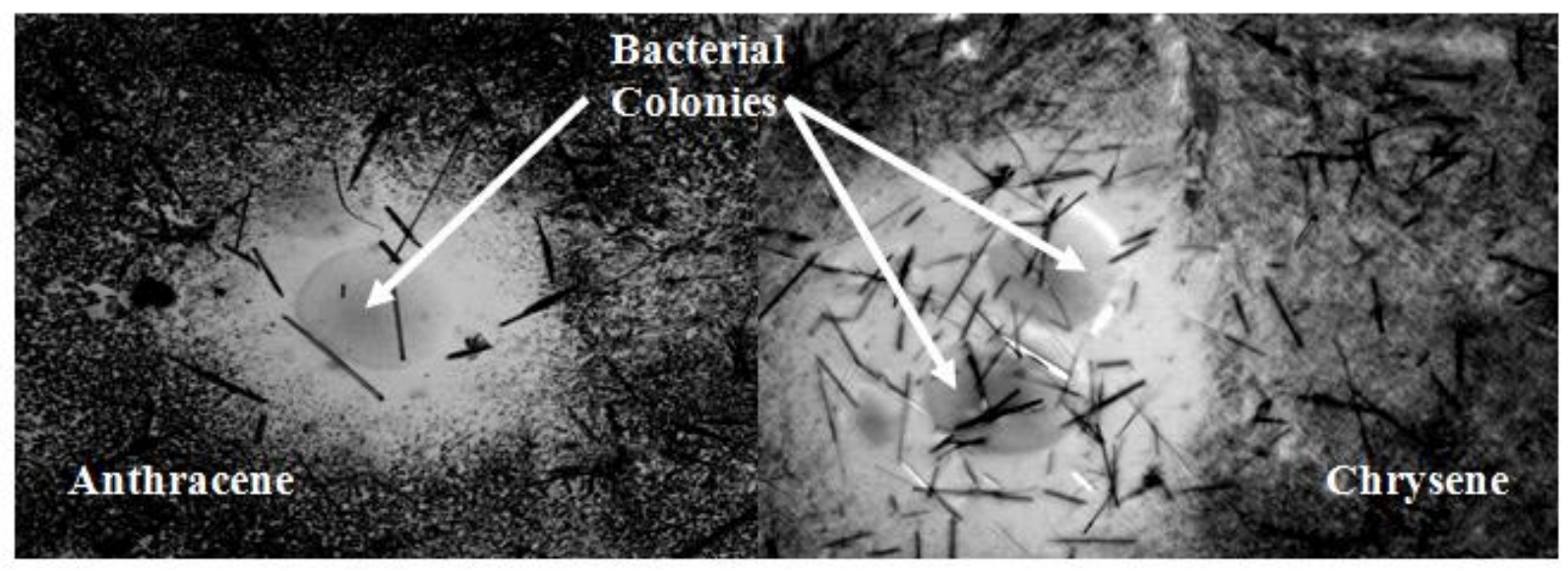

Figure 2. Microscopic images of PAH selection plates (40x magnification). Colonies showing obvious clearing zones were selected and purified. The crystal rods in the photo are larger formations of the PAHs which are evidently more difficult for the bacteria to breakdown. 


\section{ACCEPTED MANUSCRIPT}

A<smiles>c1ccc2cc3ccccc3cc2c1</smiles>

$\mathrm{C}$

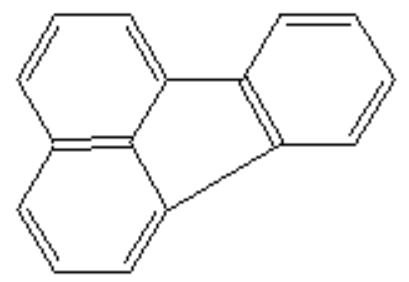

$\mathrm{F}$<smiles>O=C(O)c1cc(O)ccc1O</smiles>

B<smiles>c1ccc2c(c1)ccc1c3ccccc3ccc21</smiles>

E

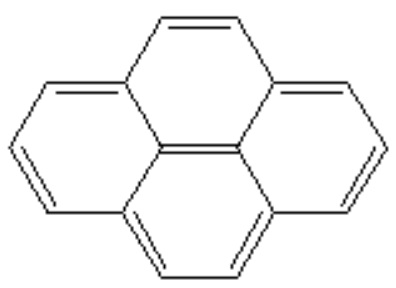

$\mathrm{H}$<smiles>O=C(O)c1ccccc1O</smiles>

Figure 3a. Chemical structures for compounds in Table 2a. A: Anthracene, B: Chysene, C:

Fluoranthene, D: Phenanthrene, E: Pyrene, F: Gentisic Acid, G: Protocatechuic Acid, H: Salicylic Acid. 


\section{ACCEPTED MANUSCRIPT}

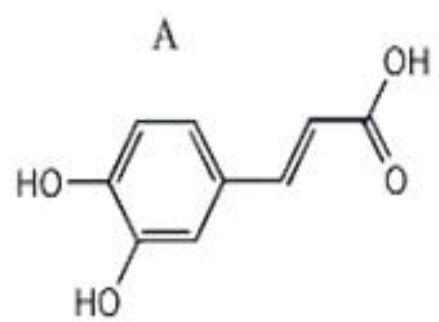

(O)

G

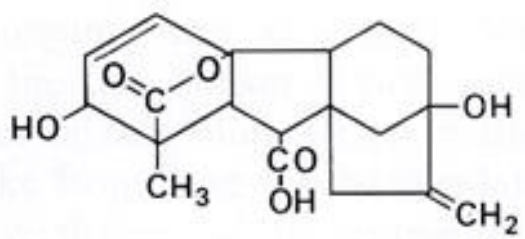

B<smiles>O=C(O)/C=C/c1ccccc1</smiles>

$\mathrm{C}$<smiles>O=C(O)/C=C/c1ccc(O)cc1</smiles><smiles>O=c1c(O)c(-c2ccc(O)cc2O)oc2cc(O)cc(O)c12</smiles>

$\mathrm{H}$

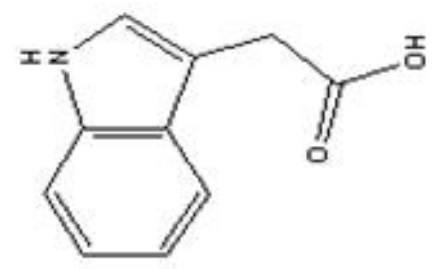

Figure 3b. Chemical structures for compounds in Table 2b. A: Caffeic Acid, B: Cinnamic Acid, C: p-Coumaric Acid, D: Naringenin, E: Quercetin, F: Morin, G: Gibberellic Acid, H: Indoleacetic Acid 